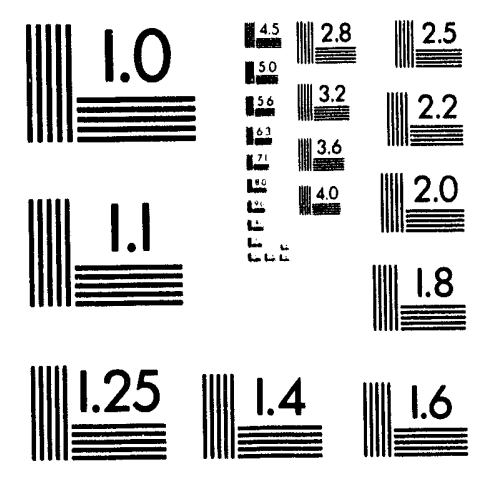



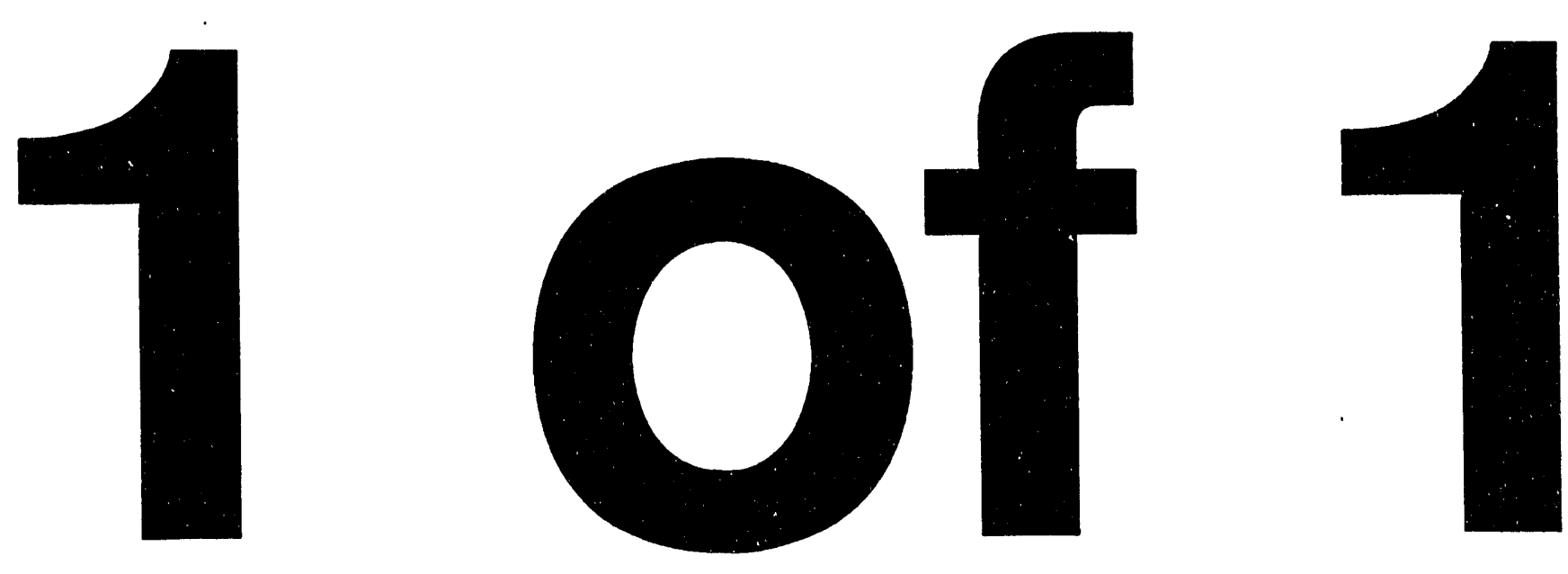


\title{
STRUCTURAL AND COMPOSITIONAL TRANSFORMATIONS OF BIOMASS CHARS DURING COMBUSTION
}

\author{
Mary J. Wornat, Robert H. Hurt,* Nancy Y. C. Yang, and Thomas J. Headley
}

Sandia National Laboratories, Combustion Research Facility and Center for Materials and Applied Mechanics, Livermore, California 94550;

Materials and Process Sciences Center, Albuquerque, New Mexico 87123

DISCLAIMER

\begin{abstract}
This report was prepared as an account of work sponsored by an agency of the United States Government. Neither the United States Government nor any agency thereof, nor any of their employees, makes any warranty, express or implied, or assumes any legal liability or responsibility for the accuracy, completeness, or usefulness of any information, apparatus, product, or process disclosed, or represents that its use would not infringe privately owned rights. Reference herein to any specific commercial product, process, or service by trade name, trademark, manufacturer, or otherwise does not necessarily constitute or imply its endorsement, recommendation, or favoring by the United States Government or any agency thereof. The views and opinions of authors expressed herein do not necessarily state or reflect those of the United States Government or any agency thereof.
\end{abstract}

Code Letter E. Experimental Data and Interpretation

Code Number 6.2. Coal and Organic Solids Combustion

The authors prefer an oral presentation and publication in the Proceedings.

*To whom corresp undence should be addressed:

Sandia National Laboratories

P. O. Box 969

40

MS 9052

Livermore, California 94551-0969

United States of America

telephone: (510) 294-3707

FAX: (510) 294-1004

DISTRIBUTION OF THIS DOCUMENT IS UNLIMITED

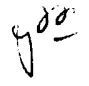

Word count

10.5 pages of text @ $320 \quad 3360$

4 figures@ $200 \quad 800$

3 tables @ $200 \quad 600$

105 lines of references @ $7 \quad \underline{735}$

5495

FEB 101934 


\begin{abstract}
In an investigation of the physical and chemical transformations of biomass chars during combustion, we have subjected two chars, produced from the pyrolysis of pine and switchgrass, to combustion at $1600 \mathrm{~K}$ in a laminar flow reactor. In order to obtain timeresolved data on the structural and compositional transformations of the biomass chars, samples are extracted from the reactor at different residence times and subjected to a variety of analytical techniques: elemental analysis, scanning electron microscopy, energy-dispersive $\mathrm{X}$-ray spectroscopy, X-ray diffraction analysis, and high resolution transmission electron microscopy. The results point to several changes in both the organic and inorganic constituents of the chars. The early stages of conversion are characterized by devolatilization, which leads to the removal of amorphous material and the release of oxygen- and hydrogen-rich gases. After devolatilization, combustion is accompanied by: vaporization of some metals (particularly $\mathrm{Na}$ and $\mathrm{K}$ ), surface migration and coalescence of inorganic material, and the incorporation of metals (particulary $\mathrm{Ca}$ ) into silicate structures. The latest stages of combustion reveal the transformation of inorganic constituents from amorphous phases to crystalline forms. Some short-range order appears in the carbon-rich portions of the chars as combustion proceeds, but the high levels of oxygen originally present in these chars foster cross-linking, which limits the extent of order ultimately attained. The transformations of the biomass chars are compared with those of coal chars, and the implications of these observations-with respect to reactivity and ash behavior-are discussed.
\end{abstract}


Introduction

In the search for fuel sources that can serve as alternatives to fossil fuels, the renewable nature of biomass places it among the more attractive options. Biomasswhich, in this context, includes wood, agricultural residues, and fast-growing crops-can either be burned directly as a combustor fuel [1-2], or it can first be upgraded by thermochemical conversion to solid [3] and liquid fuels [4-5].

In order for biomass-derived fuels to be used as substitutes for conventional fuels, several aspects of operational and environmental importance must first be examined. These aspects include ease of handling, combustion reactivity, propensity for producing aerosol or gaseous pollutants, and the tendency of inorganic components to cause fouling or corrosion of burner surfaces [6-7]. Since each of these processes is affected by the structural and compositional changes of the fuel as combustion proceeds, it is important to monitor these physical and chemical transformations of the fuel throughout the combustion process.

The present work focusses on chars produced from the pyrolysis of two biomass feedstocks - a soft wood, Southern pine; and an herbaceous material, switchgrass. The combustion reactivity of these chars is addressed in another paper [8]. The present paper reports the time-resolved physical and chemical transformations of biomass chars subjected to a combustion environment that simulates that of a pulverized fuel furnace. The analytical techniques employed include elemental analysis, scanning electron microscopy, energy-dispersive X-ray spectroscopy, X-ray diffraction analysis, and high resolution transmission electron microscopy. When appropriate, comparisons between biomass chars and coal chars are made.

\section{Experimental Equipment and Techniques}

Produced at the National Renewable Energy Laboratory (Golden, Colorado), our biomass chars are formed from pine or switchgrass particles pyrolyzed at $625^{\circ} \mathrm{C}$ in a vortex reactor described elsewhere [5]. As detailed by Wornat, et al. [8], the resulting 
biomass char particles are irregularly shaped and contain high amounts of oxygen (15 to $20 \%$ ) and residual volatile matter (20 to $25 \%$ in the ASTM test). The switchgrass char is particularly high in ash-forming constituents $(>20 \%)$.

The biomass char combustion experiments are conducted in Sandia's Char Combustion Laboratory, which features a previously described laminar flow reactor with optical access [9-10]. The stoichiometry of the reactor's $\mathrm{H}_{2} / \mathrm{CH}_{4} / \mathrm{O}_{2} / \mathrm{N}_{2}$ flame is tailored to produce post-flame gases simulating those in the upper furnace region of pulverizedfuel-fired boilers. Biomass char particles of nominal size, $75-106 \mu \mathrm{m}$, are injected upward through the center of the reactor, where they burn in 6 or 12 mole $\% \mathrm{O}_{2}$ at a mean gas temperature of approximately $1600 \mathrm{~K}$. For subsequent physical and chemical analyses, the reactor is equipped with an isokinetic He-quench sampling probe [9-10] that permits the extraction of particles at different stages during the combustion process.

The biomass char samples, extracted from the reactor at different residence times during combustion, are subjected to elemental analysis by Coors Analytical Laboratories of Golden, Colorado. The extracted samples are also analyzed by a variety of materials characterization techniques at Sandia. Particle morphology is determined by secondary electron imaging on a JEOL Model 840 scanning electron microscope operating at $15 \mathrm{kV}$. Overall surface composition is obtained from a JEOL Model 733 electron microprobe with a Tracor Northern 5502 energy-dispersive X-ray spectrometer. X-ray diffraction analyses are performed on a Rigaku diffractometer with an 18-kW high intensity rotating anode $(40 \mathrm{kV}, 20 \mathrm{~mA}, \mathrm{CuK} \alpha$ radiation). High resolution transmission electron microscopy is conducted with a Philips Model CM30 microscope, operating at $300 \mathrm{kV}$, in conjunction with an Oxford energy-dispersive X-ray spectrometer.

\section{$\underline{\text { Results and Discussion }}$}

Tables 1 and 2 present the results of the elemental analyses of the pine and switchgrass char samples, extracted from the combustor at different residence times. Listed in the first column of these tables are the conversion levels of the dry-ash-free 
portion of the chars, calculated by using the refractory element Si as tracer. Table 1 lists, as a function of char conversion, the fraction of each organic element (normalized to its original level) that is retained in the char. Table 2 presents similar results for the inorganic elements.

Table 1 indicates that within the first conversion interval (0 to $52.8 \%$ for the pine char; 0 to $48.0 \%$ for the switchgrass char), large amounts of hydrogen and oxygen are lost from the chars. These losses of $\mathrm{H}$ and $\mathrm{O}$, with relatively less severe drops in $\mathrm{C}$ and $\mathrm{N}$, correspond to the release of volatile matter, which results from the thermal scission of weaker bonds within the char structures. The release of oxygen-rich gases during the devolatilization of wood and low rank coals is well documented [2,11-14]. The absence of a visible volatiles flame during biomass char combustion suggests that the volatiles are primarily $\mathrm{CO}, \mathrm{CO}_{2}$, and $\mathrm{H}_{2} \mathrm{O}$-and not hydrocarbon gases.

As indicated in Table 1, less dramatic, yet steady releases of $\mathrm{H}$ and $\mathrm{O}$ continue from the biomass chars beyond devolatilization (the first conversion interval). These losses of $\mathrm{O}$ and $\mathrm{H}$ parallel those observed during the pyrolysis of wood, coal, and brown coal $[11,13]$ and, in several cases $[11,15-16]$, have been correlated with a decrease in carbon gasification reactivity. Despite the continuous decrease in oxygen, however, oxygen levels remain high in the biomass chars-accounting for approximately 15 to $25 \%$ of the organic portions of the chars at the higher levels of char conversion. Similar levels of oxygen are observed in the chars of low rank coals burned to comparable levels of conversion in the same reactor, but oxygen levels in high rank coal chars are an order of magnitude lower [10].

Table 1 shows that as char conversion proceeds beyond 50\%, steady losses of the other organic elements, $\mathrm{C}$ and $\mathrm{N}$, accompany those of $\mathrm{O}$ and $\mathrm{H}$. Unlike the case of coals combusted in the same reactor [10] or pyrolyzed in other reactors [17-18], nitrogen is retained preferentially to carbon in the pine and switchgrass chars. We attribute this observation to the fact that most of the carbon in the biomass chars is aliphatic, though 
nitrogen is most probably present within heterocyclic ring structures. Bonds within aliphatic material are generally more easily broken than are aromatic $\mathrm{C}-\mathrm{N}$ bonds, so nitrogen is preferentially retained in the biomass chars. In the case of coal, however, where much of the carbon is present in aromatic structures, nitrogen is more easily released than carbon since aromatic $\mathrm{C}-\mathrm{N}$ bonds require less energy to break than do aromatic C-C bonds. (Bond dissociation energies [19-20]: aliphatic C-C, $85 \mathrm{kcal} / \mathrm{mole}$; aromatic C-N ( $s p^{2}$-hybridized), $112 \mathrm{kcal} / \mathrm{mole}$; aromatic C-C, $122 \mathrm{kcal} / \mathrm{mole}$ ).

Inorganic elements also have several influences on the combustion process-from radiation [21-22] and particle temperature [23] effects to fouling and corrosion of burner surfaces [6-7]. Alkali metals [24-27], alkali earth metals [28-29], and many transition metals [30] are also known to catalyze char gasification. Although the modes of occurrence of inorganic elements in biomass chars have not been fully characterized, it is most likely, due to the high levels of oxygen in the biomass chars, that the metals $\mathrm{Na}, \mathrm{K}$, and $\mathrm{Ca}$ exist as metals ion-exchanged onto oxygen functionalities within the organic matrix. Therefore, under combustion conditions, the alkali metals $\mathrm{Na}$ and $\mathrm{K}$ would be susceptible to vaporization, as has been observed for these metals in low-rank coals and model carbons [10,31-32].

Table 2 indicates that during devolatilization, there is high retention of all of the metals withir the biomass chars. The endothermic devolatilization process prevents char particle temperatures from attaining the high values reached during combustion, so there is only minimal metal vaporization within the devolatilization regime.

After devolatilization, however, both the pine and switchgrass chars exhibit evidence of $\mathrm{Na}$ and $\mathrm{K}$ vaporization-that of the $\mathrm{Na}$ more pronounced despite the fact that $\mathrm{Na}$ (boiling point $1155 \mathrm{~K}$ ) is less volatile than $\mathrm{K}$ (boiling point $1047 \mathrm{~K}$ ) $[26,33]$. This observation underlines the importance of the form of the metal in determining vaporizability. It is possible that the reason for more vaporization of $\mathrm{Na}$ than of $\mathrm{K}$ is that $\mathrm{K}$, more electropositive than $\mathrm{Na}$ [33], is capable of forming intercalation compounds with 
carbons [26,33-34]. As Wigmans, et al. [26] point out, intercalation of $\mathrm{K}$ can prevent its vaporization during char combustion. Likewise, some forms of $\mathrm{Na}$ are volatile, e.g., $\mathrm{Na}_{2} \mathrm{O}$ and $\mathrm{NaCl}$; whereas $\mathrm{Na}$ in silicates is not [32]. Indeed, the interaction of alkali metal oxides with $\mathrm{SiO}_{2}$ and/or $\mathrm{Al}_{2} \mathrm{O}_{3}$ to form silicates and/or aluminosilicates may prevent full vaporization of $\mathrm{K}$ and $\mathrm{Na}$ from the biomass chars. According to Farris and Allen [35], conversion of potassium and sodium oxides to aluminosilicates occurs at 1000 to $1200 \mathrm{~K}$. Other works [32,36-37] suggest that interactions of $\mathrm{Na}$ metal with $\mathrm{SiO}_{2}$ to form sodium silicates are also likely-especially since silicon is so abundant in the biomass chars. These interactions would be particularly facile at particle temperatures above the melting point of $\mathrm{SiO}_{2}(1900 \mathrm{~K}$ for quartz). The in-situ optical data of our biomass char combustion experiments [8] show that a significant proportion of particles do indeed reach such temperatures.

Table 2 indicates that, compared to the alkali metals, the divalent and trivalent metals $\mathrm{Mg}, \mathrm{Ca}$, and $\mathrm{Al}$ are more highly retained in the biomass chars. These metals, however, are also lost somewhat from the chars as combustion proceeds. In some cases of solid fuel combustion [38], inorganic matter may be lost from the chars by convective transport of the gases produced from devolatilization of the solid fuel. This explanation is unlikely to hold for the biomass chars, however, since retention of the inorganic elements in Table 2 is high for both chars in the 0 to $50 \%$ conversion interval-the regime where devolatilization occurs. The decreased inorganic retention subsequent to devolatilization suggests that loss of the divalent and trivalent metals is also due primarily to vaporization. Vaporization of alkaline earth metals has been observed in the combustion of lignites [39-40], in which $\mathrm{Mg}$ and $\mathrm{Ca}$ are present mainly as ion-exchanged metals. It is likely that, as in the case of the oxygen-rich chars of low-rank coals [40], Mg and Ca are also present in the biomass chars as ion-exchanged metals associated with oxygencontaining functional groups. 
The widely dispersed nature of ion-exchanged metals in oxygen-rich chars also enhances the opportunity for alkaline earth metal interaction with $\mathrm{SiO}_{2}$ [39]. Several studies [41-43] indicate that calcium silicates form at temperatures of 1100 to $1700 \mathrm{~K}$. In addition, Lazdina et al. [44] report the binding of $\mathrm{CaO}$ to $\mathrm{SiO}_{2}$ to be accelerated in the presence of potassium, which is present in the biomass chars. As in the case of the alkali metal silicates, alkaline earth metal conversion to silicates would reduce the opportunity for vaporization of these metals. Vaporization of alkaline earth metals would also be thwarted by processes such as coalescence or sintering, observed in the combustion of lignites $[28,40,43]$, since these mechanisms reduce metal dispersion. Conversion to silicates, coalescence, and/or sintering may therefore account for the fairly high retention of the divalent and trivalent metals in the biomass chars at the later stages of conversion.

In addition to the compositional changes documented in Tables 1 and 2 , morphological changes occur to the biomass chars as they undergo combustion. Figure 1 presents the scanning electron micrographs taken of switchgrass char prior to combustion and at $91 \%$ carbon conversion. As documented elsewhere [8], Fig. 1a portrays the heterogeneous nature of the uncombusted switchgrass char-the wide variation in particle size, shape, and texture. Particularly apparent in Fig. 1 is the reduction in particle dimensions as the char undergoes combustion. The filamentous nature is generally preserved, but particle aspect ratios decrease and structures become more lace-like as burning proceeds. Similar changes occur in the pine char samples, with the preferential elimination of the fibrous pine char particles as burnout proceeds [8].

The results of the biomass char surface analyses, obtained by energy-dispersive Xray spectroscopy (EDS), are reported in Table 3 as functions of char conversion. Since calibration factors obtained for dense, pure, solid standards do not apply to porous, heterogeneous materials such as biomass chars, results are reported in terms of X-ray counts. In general, the number of each element's X-ray counts is proportional to its surface concentration, though the constant of proportionality varies from element to 
element. Sodium is listed in Table 2 but not in Table 3 since its surface composition is below the detection limit of the EDS instrument. For each level of char conversion in Table 3, the results represent averages for thousands of individual particles.

Table 3 reveals that, for both biomass chars, the O:C ratio decreases during devolatilization-consistent with the release of oxygen-rich volatile matter, as suggested by Table 1. Following devolatilization, the surface carbon concentration decreases for both chars, consistent with char burnout. As burnout proceeds, surface concentrations of all the metals increase as a result of both the consumption of carbon and the migration of inorganic elements to the surface. The increase in surface Si concentration is particularly dramatic. The increase in surface concentration of the metals is accompanied by an increase in the surface concentration of oxygen, suggesting that the metals are present in oxidized forms. The surface migration of both alkali [29] and alkaline earth metals $[40,43,45]$ has been observed during the combustion of coal chars, graphite, and activated carbons. Coalescence of inorganic components to form beads on the char surface $[40,43,46-47]$ has also been observed for coals as combustion proceeds.

Si-rich beads develop on the surfaces of the biomass chars, as evident from the scanning scanning electron micrographs of Figure 2, corresponding to switchgrass chars converted to 48 and $94 \%$. The spherical nature of these beads reveals that they have gone through a molten phase. Compared to the switchgrass char, the pine chan develops $\mathrm{Si}$-rich beads at a later stage of conversion-a result, perhaps, of the lower Si content in the uncombusted pine char (Si contents: $1.9 \%$ in the pine char; $5.4 \%$ in the switchgrass char) or a difference between the two chars in the mode of occurrence of this element.

EDS analysis of the beads in Fig. $2 a$ and $2 b$ shows that $\mathrm{K}$ is the dominant metallic element associated with the $\mathrm{Si}$ in the $48 \%$ conversion switchgrass char; in the $94 \%$ conversion sample, it is $\mathrm{Ca}$. The diminishing presence of $\mathrm{K}$ is consistent with either this element's vaporization or its intercalation with the carbon-rich portion of the char. The emerging dominance of calcium at later stages of conversion indicates that calcium 
becomes associated with $\mathrm{Si}$ at the higher levels of char conversion-consistent with the previously mentioned evidence [41-43] that, under these conditions, calcium can combine with silica to form silicates.

Figure 3 presents the results of the X-ray diffraction analyses on the pine and switchgrass chars-both the uncombusted samples and those extracted from the reactor at various stages of carbon conversion. The broad humps centered at $25^{\circ}$ and $44^{\circ}$ in the spectra correspond to amorphous material, as observed for a low rank coal [28] and for the char of a polyfurfuryl alcohol [48]. These amorphous peaks disappear from the spectra of the pine char samples as conversion proceeds from 0 to $95 \%$-indicating the loss of amorphous material (though some ambiguities of interpretation arise due to possible cation scattering [49]). Crystallinity emerges, as marked by the appearance of distinct narrow peaks in the spectra of the higher conversion samples. Altholigh the peaks in the $95 \%$ conversion sample correspond primarily to inorganic crystalline material (which also evolves in coal samples after extensive gasification [50]), the promotion of crystallinity in organic materials has also been shown to be fostered by thermal treatment [51-52] and oxidation [48]. The emergence of distinct peaks in the higher conversion samples of Fig. 3b indicates that crystalline inorganic material is also formed during switchgrass char combustion. The dominant peak at $26.7^{\circ}$ corresponds to quartz (crystalline $\mathrm{SiO}_{2}$ ), which also appears in the pine samples. Unlike the pine char, however, the switchgrass char samples show evidence of an amorphous phase even at the 94\% carbon conversion stage. Because the switchgrass chars are so high in $\mathrm{Si}$, a substantial portion of the amorphous hump may be due to noncrystalline $\mathrm{SiO}_{2}$.

A better picture of the carbon structure evolution is provided by Fig. 4, which contains high resolution transmission electron micrographs of the carbon-rich portions of the pine and switchgrass chars prior to combustion and after devolatilization. Fig. 4a and $4 \mathrm{c}$ confirm that the uncombusted pine and switchgrass chars are amorphous-i.e., there is no crystalline order observable. These micrographs resemble that of another oxygen-rich 
amorphous carbon, the char of a polyfurfuryl alcohol [48]. Comparison of Fig. $4 \mathrm{~b}$ and $4 \mathrm{~d}$ with $4 \mathrm{a}$ and $4 \mathrm{c}$ reveals that short-range turbostratic order develops during devolatilization, as oxygen-rich volatile matter is released. This observation is consistent with earlier findings that associate the loss of aliphatic and oxygen-rich material during coal devolatilization with the loss of amorphous material from coal [53-55].

After devolatilization, very little additional ordering of the carbon structure occurs in either the pine or the switchgrass chars. Even at the highest levels of conversion, the carbon-rich portions of the biomass chars do not approach the graphitic structures evident in the high resolution images of heat-treated carbon blacks [4] or carbonaceous material in high-grade metamorphic rocks [57]. Along with temperature and time, two key factors in determining the degree to which a carbonaceous material graphitizes are the oxygen and hydrogen contents of the parent materials. Studies [53,55,58-59] on a variety of carbons-including polymers, coals, and petroleum pitch-indicate the following: In order for graphitization to occur, carbon crystallites must have sufficient mobility to align and coalesce. Mobility is enhanced by hydrogen-rich organic matter, which exhibits plasticity when heated. High levels of oxygen, on the other hand, lead to the development of highly cross-linked rigid carbon structures, which hinder crystallite mobility and thus graphitization. The biomass chars contain high levels of oxygen and low levels of hydrogen (pine char, $21 \% \mathrm{O}, 3.4 \% \mathrm{H}$; switchgrass char, $22 \% \mathrm{O}, 4.1 \% \mathrm{H}$ ), so the degree of structural order attained is limited. High resolution micrographs of the char of a bituminous coal combusted to $90 \%$ conversion in the same reactor [60] show a higher degree of structural order than in the biomass chars of the same carbon conversion. The parent coal $(13 \% \mathrm{O}, 5.1 \% \mathrm{H})$ contains lower oxygen and higher hydrogen than either of the uncombusted biomass chars. It should be noted that even though a plethora of other factors influence char reactivity during gasification, reactivities are generally higher for more disordered carbons [51,61-62] since they contain a higher proportion of edge carbons, which are more reactive [63]. Therefore the inability to become very 
structurally ordered may help biomass chars ınaintain a high oxygen reactivity through the late stages of combustion.

EDS analyses of the carbon sections in Fig. 4 show these materials to contain significant levels of oxygen and $\mathrm{K}$ and $\mathrm{Ca}$, well dispersed within the carbon material. Bituminous coal chars subjected to the same procedures show $\mathrm{K}$ and $\mathrm{Ca}$ only within discrete particles. This difference probably stems from the high oxygen content of the biomass chars and its widespread distribution within the carbon structure. Calcium may be bound to the oxygen in biomass chars as ionic metal phenoxides, which are quite thermally stable (more than phenol itself) [49]. Potassium may also be present as ionic metal phenoxides or as intercalated $\mathrm{K}$, as suggested earlier [33-34]. In any case, the well dispersed distribution of these metals adds to their potential as catalysts $[28,40]$ although catalytic activity is also influenced by chemical form [27].

\section{Conclusions and Implications}

Using a variety of analytical techniques, we find that biomass chars undergo a number of structural and compositional changes during combustion. Throughout the combustion process, conversion of the biornass char particles leads to smaller diameters, smaller aspect ratios, and a more lace-like appearance. The early stages of conversion are characterized by devolatilization, which leads to the removal of amorphous material and the release of oxygen- and hydrogen-rich gases. After devolatilization, combustion is accompanied by several inorganic transformations: vaporization (particularly $\mathrm{Na}$ and $\mathrm{K}$ ), surface migration and coalescence, and the incorporation of metals (particulary $\mathrm{Ca}$ ) into silicate structures. The latest stages of combustion reveal the transformation of inorganic constituents from amorphous phases to crystalline forms. Some short-range order appears in the carbon-rich portions of the chars as combustion proceeds, but the high levels of oxygen originally present in these chars foster cross-linking, which limits the extent of order ultimately attained. Generally, the physical and chemical transformations accompanying biomass char combustion are similar to those exhibited by low rank coals. 
Our findings suggest several implications for the use of biomass chars as combustor fuels: (1) Handling and feeding operations may be complicated by the irregular morphology of the biomass chars. (2) The disordered nature of the carbon structure and the presence of alkali and alkaline earth metals in biomass chars contribute to high combustion reactivities, as demonstrated elsewhere [8]. (3) The vaporization and recondensation of alkali metals during biomass char combustion may lead to the release of submicron aerosols and to problems with fouling and corrosion of burner surfaces. (4) The incorporation of $\mathrm{Ca}$ and/or alkali metals into silicates lowers the softening temperature of ash and contributes to ash deposition. In many of these respects as well, biomass chars parallel low rank coals.

\section{Acknowledgements}

The authors gratefully acknowledge the National Renewable Energy Laboratory for financial support of this project. They also wish to thank James Ross for carefully running the char sampling experiments; Ja Lee Yio for skillfully conducting the X-ray diffraction analyses; and Bernie Bernal for carefully performing the scanning electron microscopy work. 


\section{REFERENCES}

1. Tillman, D. A. The Combustion of Solid Fuels and Wastes, Academic Press, New York, 1991, pp. 65-119.

2. Jaasma, D. R., Comb.Sci. Tech. 49:213-225 (1986).

3. Luo, M., and Stanmore, B., Fuel 71:1074-1076 (1992).

4. Elliott, D. C., Beckman, D., Bridgewater, A. V., Diebold, J. P., Gevert, S. B., and Solantausta, Y., Energy Fuels 5:399-410 (1991).

5. Diebold, J., and Scahill, J., in Pyrolysis Oils from Biomass: Producing, Analyzing, and Upgrading, ACS Symposium Series 376 (E. J. Soltes and T. A. Milne, Eds.), The American Chemical Society, Washington, D. C., 1988, pp. 31-40.

6. Crossley, H. E., J. Inst. Fuel 25:221-225 (1952).

7. Macek, A., Seventeenth Symposium (International) on Combustion, The Combustion Institute, Pittsburgh, 1978, pp. 65-75.

8. Wornat, M. J., Hurt, R. H., and Yang, N. Y. C., to be submitted to Energy.Fuels.

9. Mitchell, R. E., Twenty-Second Symposium (International) on Combustion, The Combustion Institute, Pittsburgh, 1988, pp. 69-78.

10. Mitchell, R. E., Hurt, R. H., Baxter, L. L., and Hardesty, D. R., Compilation of Sandia Coal Char Combustion Data and Kinetic Analyses: Milestone Report. Sandia National Laboratories Report No. SAND92-8208, 1992.

11. Blackwood, J. D., and McTaggart, F. K., Aust. J. Chem. 12:533-542 (1959).

12. Franklin, H. D., Cosway, R. G., Peters, W. A., and Howard, J. B., Ind. Eng. Chem., Proc. Des. Dev. 22:39-42 (1983).

13. Schafer, H. N. S., Fuel 58:673-679 (1979).

14. Wornat, M. J., and Nelson, P. F., Twenty-Third Symposium (International) on Combustion, The Combustion Institute, Pittsburgh, 1990, pp. 1239-1245.

15. Jenkins, R. G., Nandi, L. P., and Walker, P. L., Jr., Fuel 52:288-293 (1973).

16. Snow, C. W., Wallace, D. R., Lyon, L. L., and Crocker, G. R., Proc. Fourth Conf. on Carbon. Pergamon Press, Oxford, 1960, pp. 79-85.

17. Wornat, M. J., Sarofim, A. F. , Longwell, J. P., and Lafleur, A. L., Energy Fuels 2:775-782 (1988).

18. Freihaut, J. D., Zabielski, M. F., and Seery, D. J., Nineteenth Symposium (International) on Combustion, The Combustion Institute, Pittsburgh, 1982, pp. 1159-1167.

19. Morrison, R. T., and Boyd, R. N., Organic Chemistry, Fourth Edition, Allyn and Bacon, Boston, 1983. 
20. Sanderson, R. T., Chemical Bonds in Organic Compounds, Sun and Sand Publishing, Scottsdale, Arizona, 1976.

21. Sarofim, A. F., Twenty-First Symposium (International) on Combustion, The Combustion Institute, Pittsburgh, 1986, pp. 1-23.

22. Solomon, P. R., Chen, P. L., Carangelo, R. M., Best, P. E., and Markham, J. R., Twenty-Second Symposium (International) on Combustion, The Combustion Institute, Pittsburgh, 1988, pp. 211-221.

23. McCollor, D. P., Jones, M. L., Benson, S. A., and Young, B. C., Twenty-Second Symposium (International) on Combustion. The Combustion Institute, Pittsburgh, 1988, pp. 59-67.

24. Harker, H., Proc. Fourth Conf. on Carbon. Pergamon Press, Oxford, 1960, pp. 125-139.

25. Hirsch, R. L., Gallagher, J. E.,Jr., Lessard, R. R., and Wesselhoft, R. D., Science 215:121-127 (1982).

26. Wigmans, T., Haringa, H., and Moulijn, J. A., Fuel 62:185-189 (1983).

27. Yuh, S. J., Wolf, E. E. Fuel 62:252-255 (1983).

28. Radovic, L. R., Walker, P. L., Jr., and Jenkins, R. G., Fuel 62:209-212 (1983).

29. Lang, R. J., and Neveal, R. C., Fuel 61:620-626 (1982).

30. Marsh, H., and Adair, R. R., Carbon 13:327-332 (1975).

31. Mims, C. A., and Pabst, J. K., Fuel 62:176-179 (1983).

32. Neville, M., and Sarofim, A. F., Fuel 64:384-389 (1985).

33. Berger, D., Carton, B., Métrot, A., and Hérold, A., in Chemistry and Physics of Carbon (P. L. Walker, Jr., and P. A. Thrower, Ed.), Marcel Dekker, New York, 1976, Vol. 12, p. 1.

34. Kapteijn, F., Jurriaans, J., Moulijn, J. A., Fuel 62:249-251 (1983).

35. Farris, R. E., and Allen, J. E., Iron and Steel Engineer 50:67-74 (1973).

36. Brinsmead, K. H., and Kear, R. W., Fuel 35:84-93 (1956).

37. Huffman, G. P., Huggins, F. E., Shah, N., and Shah, A., Prog. Energy Comb. Sci. $16: 243-251(1990)$.

38. Baxter, L. L., "Release of Inorganic Material During Coal Devolatilization," accepted for publication in Combust. Flame.

39. Neville, M., Quann, R. J., Haynes, B. S., and Sarofim, A. F., Eighteenth Symposium (International) on Combustion, The Combustion Institute, Pittsburgh, 1981, pp. $1267-1274$. 
40. Quann, R. J., and Sarofim, A. F., Fuel 65:40-46 (1986).

41. Fierens, P., and Picquet, P., J. Am. Ceram. Soc. 58:50-51 (1975).

42. Spasov, A. V., God. Sofii Univ. Khim. Fak. 64:147-153 (1972).

43. Zygarlicke, C. J., Steadman, E. N., and Benson, S. A., Prog. Energy Comb. Sci. 16:195-204 (1990).

44. Lazdina, S., Eiduks, J., and Freidenfelds, E., Stekla Steklovidnye Pokryliya 1970: 52-56 (1970).

45. Baker, T., Chemistry and Industry 1982:698-702 (1982).

46. Hardesty, D. R., and Nissen, D. A., The Fate of Mineral Matter During Pulverized Coal Combustion, EPRI Report No. CS-5936-SR, 1988.

47. Allen, R. M., and Mitchell, R. E., Proc. 1985 Intl. Conf. on Coal Science. Pergamon Press, Sydney, 1985, pp. 401-404.

48. Levendis, Y. A., and Flagan, R. C., Carbon 27:265-283 (1989).

49. Brooks, J. D., Stephens, J. F., and Silberman, H., Proc. Fifth Biennial Conf. on Carbon. Pergamon Press, Oxford, 1962, pp. 422-428.

50. Kuhn, L., and Plogmann, H., Fuel 62:205-208 (1983).

51. Smith, W. R. and Polley, M. H., J. Phys. Chem. 60:689-691 (1956).

52. Kumar, M., Gupta, R. C., and Sharma, T., J. Materials Sci.28:805-810 (1993).

53. Franklin, R. E., Trans. Faraday Soc. 5:668-682 (1949).

54. Hirsch, P. B., Proc. R. Soc. A 226:143-169 (1954).

55. van Krevelen, D. W., Coal, Elsevier, Amsterdam, 1961.

56. Ban, L. L., in Surface and Defect Properties of Solids, The Chemical Society, London, Volume 1, pp. 54-94 (1972).

57. Buseck, P. R., and Bo-Jun, H., Geochim. Cosmochim. Acta 49:2003-2016 (1985).

58. Oberlin, A., Bonnamy, S., Bourrat, X., Monthioux, M., and Rouzaud, J. N., in Petroleum-Derived Carbons, ACS Symposium Series 303 (J. D. Bacha, J. W. Newman, and J. L. White, Eds.), The American Chemical Society, Washington, D. C., 1986, pp. 85-98.

59. Marsh, H., Diez, M. A., and Kuo, K., in Fundamental Issues in Control of Carbon Gasification Reactivity (J. Lahaye and P. Ehrburger, Eds.), Kluwer, Amsterdam, 1991, p. 205.

60. Davis, K. A., Hurt, R. H., Yang, N. Y. C., and Headley, T. J., submitted to the Twenty-Fifth Symposium (International) on Combustion, Irvine, California, 1994. 
61. Duval, X., Annales de Chimie 10:903-967 (1955).

62. McEnaney, B., and Willis, M. A., in High Temperature Chemistry of Inorganic and Ceramic Materials (F. P. Glasser and P. E. Potter, Ed.), The Chemical Society, London, 1977, p.102.

63. Laine, N. R., Vastola, F. J., Walker, P. L., Jr., J. Phys. Chem. 67:2030-2034 (1963). 
Table 1. Organic Element Retention in the Biomass Chars

Char Conversion

\% dry ash-free)

Southern Pine

0

52.8

73.0

86.4

94.6

Switchgrass

0

48.0

76.3

90.7

93.9 $\underline{\operatorname{mass}}^{\mathrm{a}}$

1

.472

.270

.136

.054

1

.520

.237

.093

.061
Normalized Fractional Retention in the Char

$\underline{\mathrm{C}} \quad \underline{\mathrm{H}} \quad \underline{\mathrm{O}} \quad \underline{\mathrm{N}}$

$\begin{array}{llll}1 & 1 & 1 & 1 \\ .562 & .082 & .157 & .694 \\ .314 & .054 & .126 & .532 \\ .154 & .020 & .088 & .394 \\ .053 & .010 & .049 & .172\end{array}$

a normalized char mass on a dry ash-free basis

$\begin{array}{llll}1 & 1 & 1 & 1 \\ .626 & .146 & .237 & .582 \\ .225 & .044 & .118 & .349 \\ .104 & .019 & .066 & .222 \\ .065 & .018 & .060 & .126\end{array}$

Table 2. Inorganic Element Retention in the Biomass Chars ,

Char Conversion

(\% dry ash-free)

Southern Pine

0

52.8

73.0

86.4

94.6

Switchgrass

0

48.0

76.3

90.7

93.9
Normalized Fractional Retention in the Char

$\underline{\mathrm{Na}} \quad \underline{\mathrm{Mg}}$

Al

$\underline{\mathrm{K}}$

$\underline{\mathrm{Ca}}$

1

$1 \quad .980$

.455

.449

.313

.931

.917

.827

1
.762
.692
.729
.878

1

.928

.887

.599

.468

1

.997

.962

.973

.789 
Table 3. Overall Elemental Surface Analyses of the Biomass Chars

Char Conversion Net X-ray counts from each element on the char surface (\% dry ash-free) (carbon values absolute; all other elements ratioed to carbon)

\begin{tabular}{|c|c|c|c|c|c|c|c|}
\hline & $\underline{\mathrm{C}}$ & $\mathrm{O} / \mathrm{C}$ & $\mathrm{Mg} / \mathrm{C}$ & $\mathrm{Al} / \mathrm{C}$ & $\underline{\mathrm{Si} / \mathrm{C}}$ & $\underline{\mathrm{K} / \mathrm{C}}$ & $\mathrm{Ca} / \mathrm{C}$ \\
\hline \multicolumn{8}{|c|}{ Southern Pine } \\
\hline 0 & 20384 & .243 & .0212 & .0137 & .256 & .093 & .055 \\
\hline 52.8 & 30513 & .161 & .0473 & .0111 & .445 & .149 & .136 \\
\hline 73.0 & 21994 & .252 & .0727 & .0202 & .750 & .275 & .282 \\
\hline 86.4 & 11641 & .348 & .1045 & .0582 & 1.468 & .441 & .497 \\
\hline 94.6 & 9271 & .737 & .1290 & .0681 & 2.847 & .597 & .466 \\
\hline \multicolumn{8}{|c|}{ Switchgrass } \\
\hline 0 & 22528 & .393 & .0466 & .0280 & .697 & .156 & .092 \\
\hline 48.0 & 21188 & .323 & .0599 & .0284 & 1.159 & .349 & .227 \\
\hline 76.3 & 12285 & .789 & .0756 & .0643 & 3.445 & .871 & .507 \\
\hline 90.7 & 9615 & 1.320 & .2264 & .1302 & 5.380 & .989 & .674 \\
\hline 93.9 & 7756 & 1.643 & .3140 & .1462 & 7.152 & 1.326 & .915 \\
\hline
\end{tabular}

$\underline{\mathrm{C}} \quad \underline{\mathrm{O} / \mathrm{C}} \quad \underline{\mathrm{Mg} / \mathrm{C}} \quad \underline{\mathrm{Al} / \mathrm{C}} \quad \underline{\mathrm{Si} / \mathrm{C}} \quad \underline{\mathrm{K} / \mathrm{C}} \quad \underline{\mathrm{Ca} / \mathrm{C}}$ 


\section{FIGURE CAPTIONS}

Figure 1. Scanning Electron Micrographs of Switchgrass Chars. Magnification, 100x. (a) uncombusted char; (b) sample removed from the laminar flow reactor after burning in 12 mole $\% \mathrm{O}_{2}$ for $95 \mathrm{msec}(90.7 \%$ conversion daf).

Figure 2. Scanning Electron Micrographs of Switchgrass Chars. Samples removed from the laminar flow reactor after burning in 12 mole $\% \mathrm{O}_{2}$ for (a) $47 \mathrm{msec}(48.0 \%$ conversion daf), 1500x magnification; (b) $117 \mathrm{msec}(93.9 \%$ conversion daf), $2500 \mathrm{x}$ magnification.

Figure 3. X-Ray Diffraction Patterns for Biomass Chars at Various Extents of Reaction. (a) Pine char, uncombusted and at conversions of 53,73, 86, and $95 \%$ daf. (b) Switchgrass char, uncombusted and at conversions of 76 and $94 \%$ daf.

Figure 4. High Resolution Transmission Electron Micrographs of Carbon-Rich'Portions of the Biomass Chars. (a) uncombusted pine char; (b) pine char sample at $53 \%$ conversion daf; (c) uncombusted switchgrass char; (d) switchgrass char sample at $48 \%$ conversion daf. 

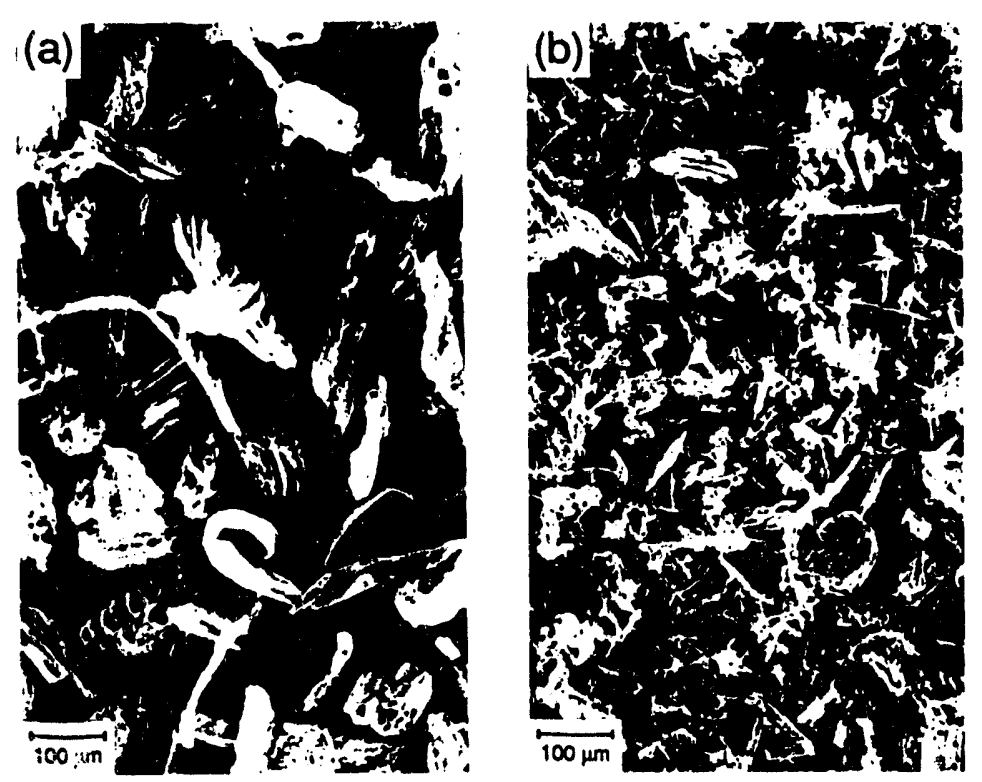

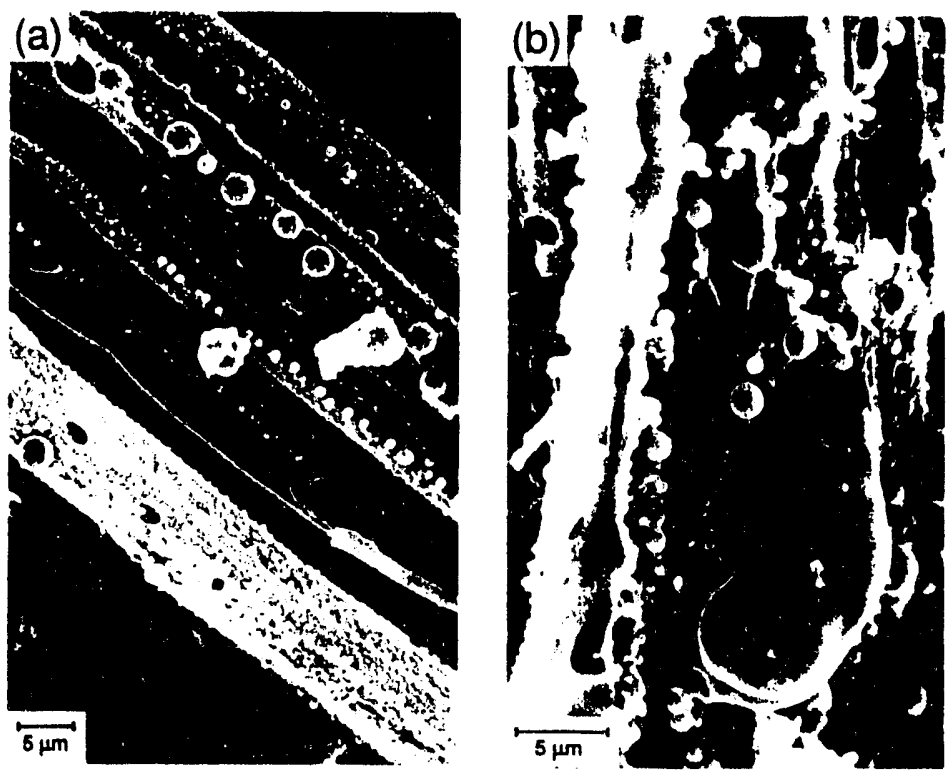


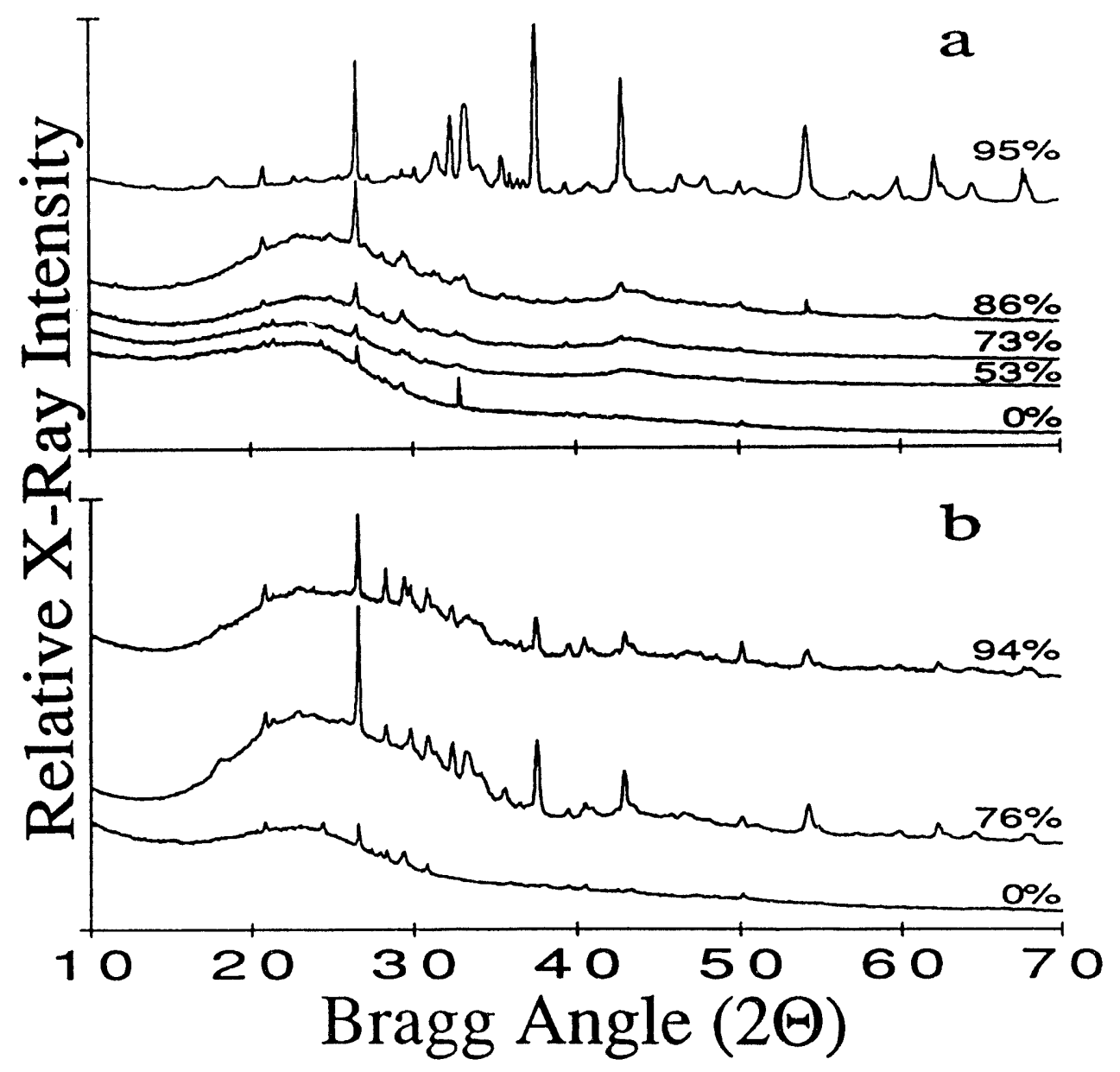



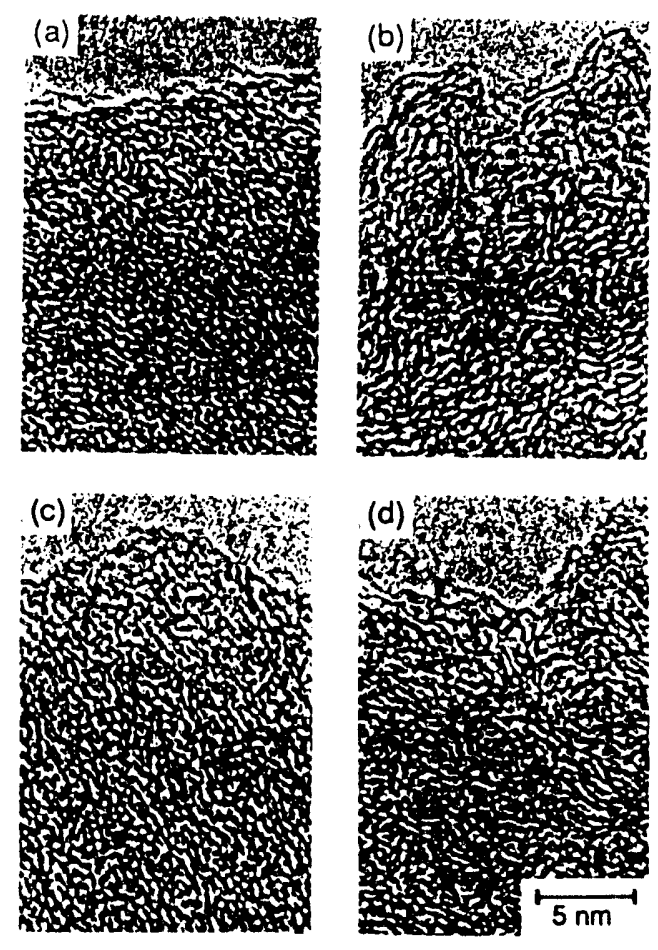

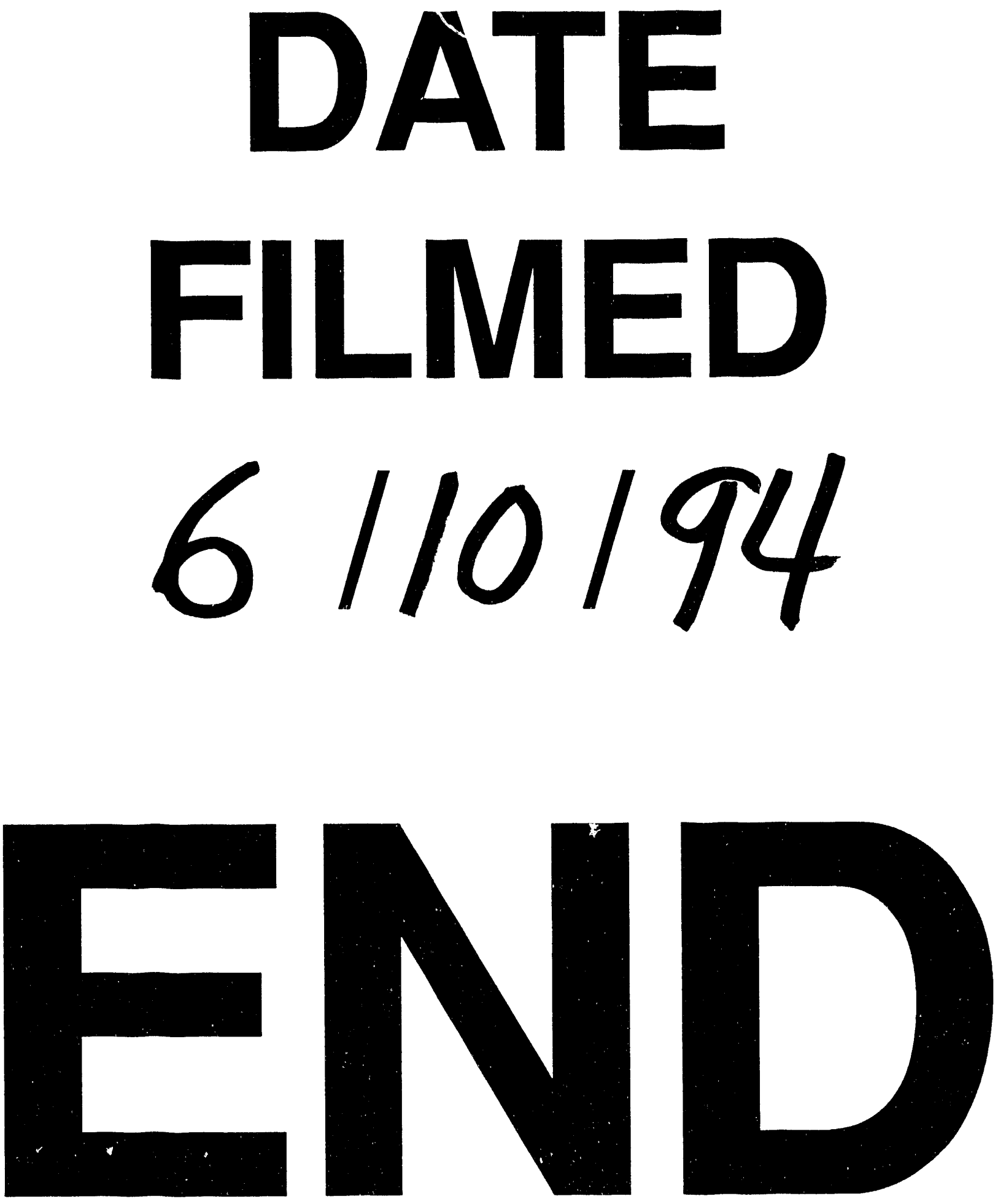